\title{
The Matrix and Isolation in Close Relationship with The Isolated Strains Showing Benefits Against Pathogens; The Hope Is Right in Front of Us to Combat Multi Resistant Bacteria
}

\author{
Sandra Quilodrán Vega* \\ Faculty of Veterinary Sciences, University of Concepción, Chile
}

\section{OPINION}

The correct isolation of beneficial bacteria from different matrix in the nature is a very important key to find the right microorganism with effect against pathogens. Beneficial microorganisms are necessary, since de WHO incited the world to decrease the application of antibiotics because of the consequences of multi resistant's microorganism's selection [1]. Those microorganisms are interfering with the therapies all over the world. Today there is no treatment for a several diseases, like gonorrhoea, tuberculosis, nosocomial infections (Acinetobacter baumannii, Staphylococcus aureus) etc.

To isolate microorganisms from different matrix, first is necessary to know about the pathogen you would like to target. Then the matrix must be chosen, and that's mean that it should probably have similar characteristics for the pathogen survival too. And this is a very important point, because it is related to the technic to use to determinate the effect of the beneficial bacteria against the pathogen. So, if the pathogen can develop in the same media of the beneficial bacteria, you can use diffusion agar test, for example, or any assay that can be carry in the same media. If the beneficial bacteria do not develop in the same media, you will have to use maybe spot soft agar technic, since this technic allows booths strains to develop in their ideal media and physical conditions. This way we can determinate the effect against the pathogen using the alive beneficial bacteria. Moreover, science can use and put together other strategies to improve the power of their strains for the beneficial effect, like immunomodulatory determination effects, production of antimicrobial molecules, mucus production, antiinflammatory responses, etc. All the characteristics that should be consider important must be observed accorded to the microniche of the pathogen and the supervene of the beneficial bacteria, and if the beneficial bacteria are functional under that conditions in vitro and in vivo. That's why is not so simple to choose a good strain. Sometimes, it is not enough to be a good strain, so the scientific world must search for new strains constantly.

Is very important to consider a multiprotection and technological team in your laboratory, because the focuses are very distinct one from other and so the expertise. One of the concluding remarks of these researches is that applicable science can offer effective solutions for big problems, but first the world must know what it has been doing to eradicate multi resistant bacteria and then to believe that there is other opportunities to eradicate lethal microorganisms by choosing the correct matrix for isolation of beneficial bacteria based on the characteristics of the pathogen too.

Of course, education must be side by side with the roll of the health care and professionals of the area. We must establish a net of wise. That's my experience in the most beautiful and giant world of beneficial microorganisms.

\section{REFERENCES}

1. World Health Organization (2015) Global action plan on antimicrobial resistance. WHO library cataloguing-in-publication data. WHO document production services, Geneva, Switzerland.

\begin{tabular}{|l|l|} 
Quick Response Code: & $\begin{array}{l}\text { Address for correspondence: Sandra Quilodrán-Vega, University of Concepción, } \\
\text { Chillán, Chile }\end{array}$ \\
\cline { 2 - 2 } & $\begin{array}{l}\text { Received: December 02, } 2019 \quad \text { Published: December 05, } 2019 \\
\text { How to cite this article: Sandra Quilodrán V. The Matrix and Isolation in Close Relationship } \\
\text { with The Isolated Strains Showing Benefits Against Pathogens; The Hope Is Right in Front of } \\
\text { Us to Combat Multi Resistant Bacteria. 2019 - 1(3) OAJBS.ID.000126. } \\
\text { DOI: 10.38125/OAJBS.000126 }\end{array}$ \\
\end{tabular}

